TITLE:

\title{
Heterospecific and conspecific social cognition in the anterior cingulate cortex(Abstract_要旨 )
}

\section{$\operatorname{AUTHOR}(\mathrm{S})$ :}

Shinozaki, Jun

\section{CITATION:}

Shinozaki, Jun. Heterospecific and conspecific social cognition in the anterior cingulate cortex. 京都大学, 2008, 博士(医学)

\section{ISSUE DATE:}

2008-03-24

URL:

http://hdl.handle.net/2433/135801

RIGHT: 


氏 名篠㟝涪等

学位 (専攻分野) 博士(医学)

学位記番号医 博 第 3181 号

学位授与の日付平成 20 年 3 月 24 日

学位授与の要件 学 位 規 則 第 4 条第 1 項 該 当

研究科 - 専攻医学研究科脳統御医科学系専攻

学位論文題目 Heterospecific and conspecific social cognition in the anterior cingulate cortex

（社会的認知機能は対象が異種か同種かによって前帯状回の異なった部位で表 象される)

論文調查委員教主授查) 河野憲二教授林拓二教授高橋良輔

\section{論文内容の要旨}

背景 他者の表情や行動から相手の情動や意図を理解・推測する機能である社会的認知機能は, 集団内に打ける適切な関係 性を構築する上で重要な役割を持つ，社会的認知機能は典型的には対象が同種である場合に活性化するが，ヒトとイヌとの 互恵的関係に見られるように，ヒトの場合は社会的認知機能を異種に対してあ拡張してきた．このことから，異種に対する 社会的認知機能を担う神経基盤が存在すると考えられた。 そこで本研究ではヒトとイヌの両方に社会的関係性を持っている ヒト（愛犬家）の顔認知機能に着目し，同種（ヒト）と異種（イヌ）に対する社会的認知機能を表象している神経基盤を明 らかにするために行った。

方法 愛犬家に, 自身の家族の顔写真・自身の飼い犬の顔写真, 対照として事前に覚えてもらった人の顔写真・事前に覚え てもらった犬の顔写真をMRI スキャナの中で見てもらい，そのときの脳活動を測定した．さらに被験者が日常使用する見 慣れた自分の物（携帯電話など）, 対照として事前に覚えてあらった他人の物をMRI スキャナの中で見てあらい，そのとき の脳活動を測定した。得られた機能画像はSPM2 を用いて体動補正・空間的標準化・統計処理を行った。また，各被験者の 飼い犬からの情緒的サポートと家族からの社会的サポートを質問紙法により数值化した.

結果 吻腹側前帯状回が自身の家族と自身の飼い犬の顔写真を見たときに共通して有意に強い活動を示した。さらに，自身 の飼い犬からの情緒的サポート尺度得点とこの部位の活動との間に有意な正の相関が認められた。また，尾側前帯状回が自 身の家族に特異的に有意に強い活動を示し, その活動は自身の家族からの社会的サポート尺度得点との間に有意に相関した。 これらに対して，単に見慣れた物では前帯状回の有意な賦活は見られなかった。

考察 単に日常使用する見慣れた自分の物，すなわち社会的関係性のない物では前帯状回の有意な賦活は見られなかったこ とから, 本研究で示された吻腹側前帯状回と尾側前帯状回の賦活は社会的関係性に関与しており, 前者が同種と異種に共通 した社会的認知機能に，後者が同種に特異的な社会的認知機能に関与していると考えられる.

また, 既存の研究から前帯状回は解剖学的にあ機能的にも吻腹側部位と尾側部位とに分けられることが示されており, 吻 腹側部位は情動的側面に, 尾側部位は分析的側面を担っていることが示唆されている. 本研究で吻腹側前帯状回の活動が情 緒的サポート尺度点数と比例し, 尾側前帯状回の活動が社会的サポート尺度点数と比例したことから, 吻腹側前帯状回と尾 側前帯状回はそれぞれ，社会的認知機能の情動的側面，分析的側面を担っていると考えられる.

結論 社会的認知機能は対象が異種か同種かによって前帯状回の異なった部位で表象されることを示した。また，ヒトの社 会的認知機能は解剖学的にも機能的にも階層的性質を有することが示唆された. 


\section{論 文 審 査 の 結 果 の 要 旨}

社会的認知機能は, 他者の表情や特性から相手の情動や意図を理解・推測する機能であり, 集団内における適切な関係性 を構築する上で重要な役割を持つ。典型的には，社会的認知機能は対象が同種である場合に働くが，ヒトとイヌとの互恵的 関係に見られるように，ヒトの場合は社会的認知機能を異種に対しても拡張してきた。 このことから，異種に対する社会的 認知機能を担う神経基盤が存在すると考えられた。そこで本研究はヒトとイヌの両方に社会的関係を持っているヒト（愛犬 家）の顔認知機能に着目し，同種（ヒト）と異種（イヌ）に対する社会的認知機能に関連している神経基盤を明らかにする ために行った。

その結果, 吻腹側前帯状回が同種（ヒト）と異種（イヌ）に共通した社会的認知機能に，尾側前帯状回が同種（ヒト）に 特異的な社会的認知機能に関与していることを示した。 また心理尺度点数との相関解析から, 吻腹側前帯状回と尾側前帯状 回はそれぞれ，社会的認知機能の情動的側面，分析的側面に関与していることを示した.

これらの結果から，ヒトの社会的認知機能は対象が異種か同種かによって前帯状回の異なった部位で処理され，解剖学的 にも機能的にも階層的性質を有していると結論付けた.

以上の研究は, ヒトの社会的認知機能における解剖学的㧍よび機能的性質の解明に貢献し, 神経科学の発展に寄与すると ころが大きい.

したがって, 本論文は博士 (医学) の学位論文として価值あるあのとして認める.

なお，本学位授与申請者は，平成 19 年 12 月 19 日実施の論文内容とそれに関連した試問を受け，合格と認められたもので ある. 